\title{
Continuous exhumation of mantle-derived rocks at the Southwest Indian Ridge for 11 million years
}

\author{
Daniel Sauter ${ }^{1 \star}$, Mathilde Cannat ${ }^{2}$, Stéphane Rouméjon ${ }^{2}$, Muriel Andreani ${ }^{3}$, Dominique Birot ${ }^{4}$, \\ Adrien Bronner ${ }^{1}$, Daniele Brunelli ${ }^{5}$, Julie Carlut ${ }^{2}$, Adélie Delacour ${ }^{6}$, Vivien Guyader ${ }^{4}$, \\ Christopher J. MacLeod ${ }^{7}$, Gianreto Manatschal ${ }^{1}$, Véronique Mendel', Bénédicte Ménez², \\ Valerio Pasini $^{2,5}$, Etienne Ruellan ${ }^{8}$ and Roger Searle ${ }^{9}$
}

\begin{abstract}
The global mid-ocean ridge system, where tectonic plates diverge, is traditionally thought of as the largest single volcanic feature on the Earth. Yet, wide expanses of smooth sea floor in the easternmost part of the Southwest Indian Ridge in the Indian Ocean lacks the hummocky morphology that is typical for submarine volcanism. At other slow-spreading ridges, the sea floor can extend by faulting the existing lithosphere, along only one side of the ridge axis. However, the smooth sea floor in the easternmost Southwest Indian Ridge also lacks the corrugated texture created by such faulting. Instead, the sea floor is smooth on both sides of the ridge axis and is thought to be composed of altered mantle-derived rocks. Here we use side-scan sonar to image the sea floor and dredge samples to analyse the composition of two sections of the Southwest Indian Ridge, between $62^{\circ} 05^{\prime} \mathrm{E}$ and $64^{\circ} 40^{\prime} \mathrm{E}$, where the sea floor formed over the past 11 million years. We show that the smooth floor is almost entirely composed of seawater-altered mantle-derived rocks that were brought to the surface by large detachment faults on both sides of the ridge axis. Faulting accommodates almost $100 \%$ of plate divergence and the detachment faults have repeatedly flipped polarity. We suggest that this tectonic process could also explain the exhumation of mantle-derived rocks at the magma-poor margins of rifted continents.
\end{abstract}

T he easternmost part of the Southwest Indian Ridge $e^{1,2}$ (SWIR), spreading at the ultraslow rate of $\sim 14 \mathrm{~mm} \mathrm{yr}^{-1}$ (ref. 3), is among the deepest parts of the oceanic ridge system, and it is inferred to represent a melt-poor endmember for this system ${ }^{4}$. There, a very low magma supply is inferred from bathymetric, gravity, seismic and geochemical data ${ }^{4-10}$. The axis in this part of the SWIR exhibits a segmentation that differs widely from what is observed at slow-spreading ridges such as the Mid-Atlantic Ridge $^{11,12}$. High-relief volcanic ridge segments are linked by $>100$ $\mathrm{km}$-long, deep axial sections with almost no volcanic activity ${ }^{13}$. The ridge flanks exhibit non-volcanic sea floor that has been called smooth sea floor because it occurs in the form of broad ridges with a smooth, rounded topography with no resolvable volcanic cones on bathymetric data ${ }^{14}$. This new type of sea floor has no equivalent at slow- to fast-spreading ridges. Its occurrence at the easternmost part of the SWIR provides an opportunity to investigate the mode of formation of non-volcanic oceanic lithosphere in a melt-poor region at the slowest end of the spreading-rate spectrum.

\section{Sampling and imaging the smooth seafloor}

In 2010, during RV Marion Dufresne cruise MD183, we acquired side-scan sonar imagery (Towed Ocean Bottom Instrument, TOBI) and dredged extensively in two spreading corridors (Fig. 1, Methods and Supplementary Figs S1 and S2). The western corridor is located within a large smooth seafloor domain exhibiting broad $\sim 40$-km-long ridges, oriented southwest-northeast oblique to the approximately north-south-spreading direction. The eastern corridor includes both volcanic and smooth seafloor areas, with ridges near-orthogonal to the spreading direction, and two corrugated oceanic core complexes. More than $1,000 \mathrm{~km}$ of TOBI images were collected out to $100 \mathrm{~km}$ from the ridge axis on flow lines extending up to $\sim 11 \mathrm{Myr}$ (magnetic anomaly C5n.o) in the eastern corridor. To complement 11 previous dredges ${ }^{9}$, we made 35 more recovering a total of about 7,200 kg of hard rocks (Supplementary Table S1). Two new dredges targeted volcanic areas and 33 the smooth sea floor. Dredge tracks were typically $1 \mathrm{~nm}$ in length. Over 1,200 discrete samples were described petrographically.

Smooth seafloor ridges of the western corridor mostly exhibit a symmetric cross-sectional shape with slopes dipping $16^{\circ}-20^{\circ}$ on average on both sides of a sharp summit (Figs $2 \mathrm{a}$ and 3 and Supplementary Fig. S1). One of these ridges (called Cannibal Ridge) is observed within the axial domain. TOBI images show that the hillsides of Cannibal Ridge correspond to smooth homogeneous backscatter surfaces with evidence for mass-wasting features but

\footnotetext{
${ }^{1}$ Institut de Physique du Globe de Strasbourg, UMR CNRS 7516, Université de Strasbourg, 1 rue Blessig, 67084 Strasbourg cedex, France, ${ }^{2}$ Equipe de Géosciences Marines, Institut de Physique du Globe de Paris, Sorbonne Paris Cité, Univ Paris Diderot, UMR CNRS 7154, 75005 Paris, France, ${ }^{3}$ Laboratoire des Sciences de la Terre, ENS et Université de Lyon, 2 rue Raphael Dubois, 69622 Villeurbanne Cedex, France, ${ }^{4}$ Ifremer-Centre de Brest, Département Géosciences Marines, Laboratoire Géochimie-Métallogénie, B.P. 70, 29280 Plouzané, France, ${ }^{5}$ Dipartimento di Scienze della Terra, Università di Modena e Reggio Emilia, Lgo St. Eufemia, 19-41100 Modena, Italy, ${ }^{6}$ Département de Géologie, Université Jean Monnet, UMR CNRS 6524, 23 rue du Docteur Paul Michelon, 42023 Saint Etienne Cedex 2, France, ${ }^{7}$ School of Earth and Ocean Sciences, Cardiff University, Main Building, Park Place, Cardiff CF10 $3 Y E$, UK, ${ }^{8}$ OCA-UNS-GéoAzur, UMR CNRS 7329, 250 Rue Albert Einstein, Sophia Antipolis, 06560 Valbonne, France, ${ }^{9}$ Department of Earth Sciences, Durham University, Durham DH1 3LE, UK. *e-mail: daniel.sauter@unistra.fr.
} 


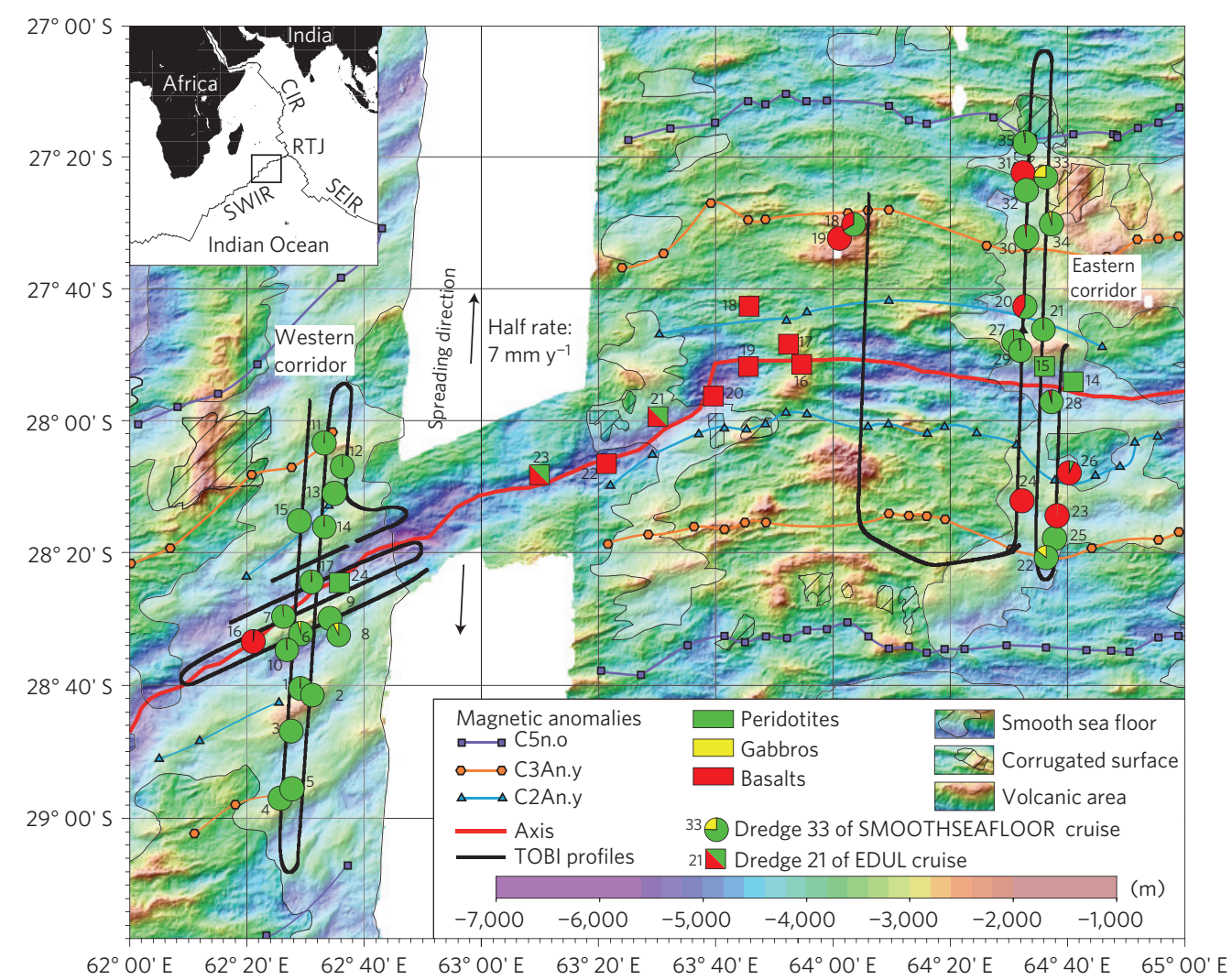

Figure 1 | Bathymetric map with the side-scan sonar tracks and dredges of the SMOOTHSEAFLOOR cruise on the SWIR. The proportion by weight of magmatic and mantle-derived rocks is shown as individual pie charts for each dredge station (16 in the axial domain and 30 on the flanks), colour coded by rock type. The squares indicate dredges from an earlier cruise ${ }^{9}$. The different types of sea floor (corrugated surfaces, volcanic and non-volcanic smooth seafloor areas) are from ref. 14. Magnetic anomaly identifications are from ref. 16. RTJ, Rodrigues Triple Junction; CIR, Central Indian Ridge; SEIR, Southeast Indian Ridge.

without volcanic textures nor corrugations (Fig. 2a). Five dredge hauls that targeted both sides of Cannibal Ridge in its central part recovered serpentinized mantle-derived peridotites almost exclusively; gabbros comprised less than $3 \%$, and basalt was absent entirely (Supplementary Table S1). The only known example of such distinctive basement uplift at a divergent plate boundary has been found at Lena Trough in the Arctic Ocean in which subcontinental lithospheric mantle rocks are exhumed ${ }^{15}$. Although Cannibal Ridge is located at the centre of the axial domain, the central magnetic anomaly $(\mathrm{C} 1$; ref. 16$)$ is located off-centre in the northern deep part of the axial domain, where it coincides with agglomerations of small volcanic hummocks (Fig. 2a). In contrast, thicker sediments without volcanic textures are shown by dark and homogeneous backscatter surfaces on TOBI images of the southern part of the axial domain. Faulted and uplifted hummocky volcanic areas are also imaged at the western and eastern end of the Cannibal Ridge with no evidence for a neovolcanic ridge similar to those commonly found in the axial valley of slow-spreading ridges ${ }^{17}$. Pillow basalts with fresh thick glassy rims were recovered in these hummocky terranes. Off-axis, dredge hauls that targeted the smooth homogeneous surfaces, facing both towards and away from the axis, recovered almost entirely serpentinized peridotites (with less than $1 \%$ gabbros and basalts). Low-backscatter volcanic hummocks concealed by sediments are suspected very locally at the top of the off axis smooth ridges (Fig. 3). Out of eight smooth ridges investigated in the western corridor, only one is partly covered by significant expanses of volcanic hummocks (Figs $2 \mathrm{a}$ and 3 ). Draping the TOBI images on bathymetric data reveals that this volcanic layer is $<100-200 \mathrm{~m}$ thick, discontinuously capping the ultramafic basement. Thus, both the dredge statistics and the interpretation of the acoustic imagery from the western corridor show that the magmatic crust is virtually absent in the western corridor.

Most ridges within the smooth seafloor area of the eastern corridor have an asymmetric cross-sectional shape (Fig. 3). The inward-facing gentle-dipping slope $\left(5^{\circ}-9^{\circ} \mathrm{dip}\right)$ of these asymmetric ridges extends over spreading-direction-parallel distances up to $17 \mathrm{~km}$ (Fig. 2b). TOBI images show that these gentle slopes are mostly smooth homogeneous surfaces and without corrugation, locally covered by volcanic hummocks (Supplementary Fig. S2). Outward-facing slopes are shorter and steeper $\left(12^{\circ}-21^{\circ}\right.$ dip $)$ and are often at least partly recovered by volcanic textures. The axial valley inner floor corresponds to a smooth slope dipping $5^{\circ}$ northward (Fig. 2b). There, a neovolcanic ridge, prominent in a more volcanically active area to the west, shrinks over a few kilometres and disappears. Small fresh-looking scarps $(<100 \mathrm{~m}$ high), near-orthogonal to the spreading direction, cut the lightly sedimented smooth basement, and are locally sealed by volcanic hummocks (Fig. 4). This indicates that the volcanics were emplaced directly on the faulted and lightly sedimented basement. About 3-km-wide agglomerations of volcanic hummocks, less sedimented than the adjacent basement, are also observed over smooth off-axis areas ( $\alpha$ in Fig. 4). Another patch of hummocks is observed at the base of the northern axial valley wall ( $\beta$ in Fig. 4 ). This patch dips up to $27^{\circ}$ and seems to be faulted against the underlying basement upslope, whereas hummocks at the base of the wall rest directly on sedimented smooth basement as observed elsewhere ( $\beta$ in Fig. 4). This suggests that the northern axial valley wall is the footwall of a recent large fault cutting the earlier sedimented smooth inner floor and slicing its volcanic carapace. Dredge hauls 


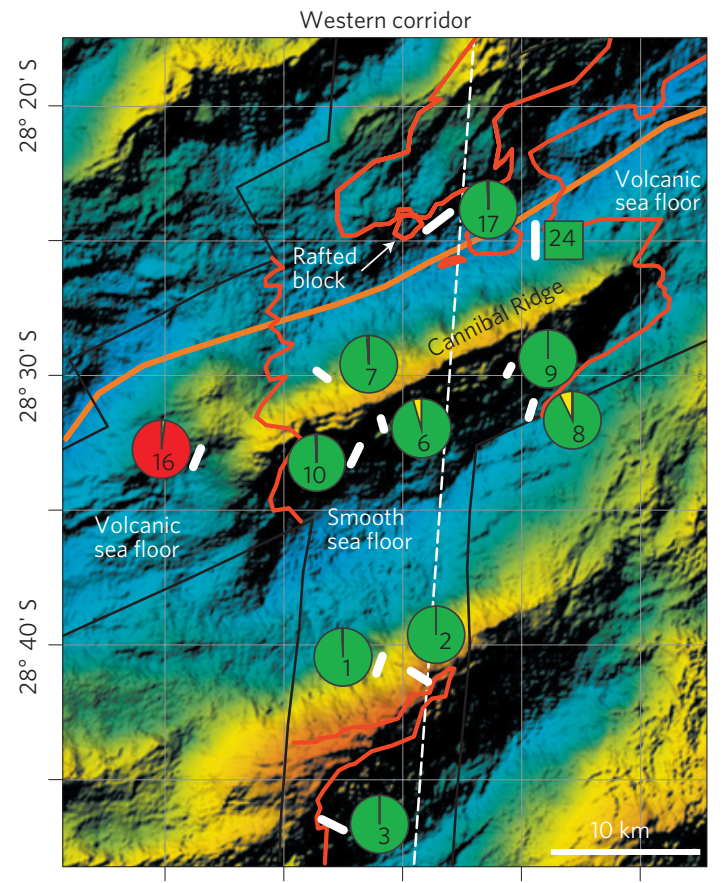

$62^{\circ} 30^{\prime} \mathrm{E}$

$62^{\circ} 40^{\prime} \mathrm{E}$

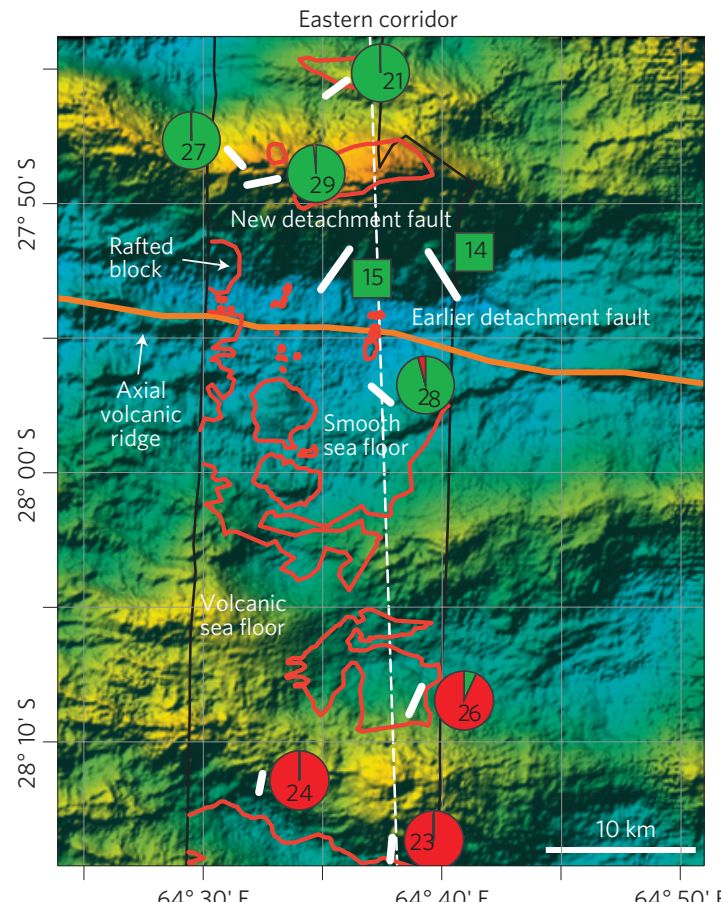

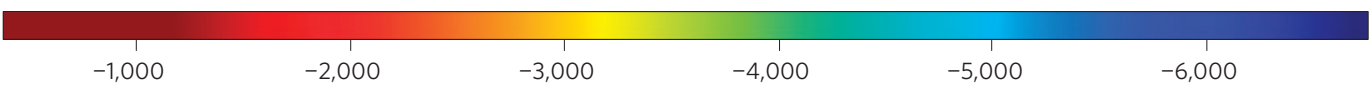

$(\mathrm{m})$
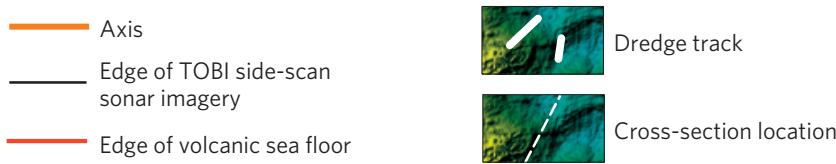

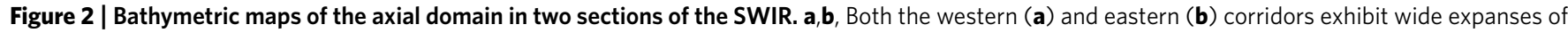
mantle-derived rocks. The edges of the volcanic areas are deduced from the interpretation of the TOBI side-scan sonar images. The pie charts are as in Fig. 1. Dashed white lines indicate the locations of the cross-sections shown in Fig. 3.

that targeted the smooth areas in the axial domain recovered $97 \%$ serpentinized peridotites. These observations together constitute direct evidence for cross-cutting mantle exhumation faults at mid-oceanic ridges. Off-axis, dredge hauls on slopes facing both towards and away from the ridge axis, recovered $85 \%$ serpentinized peridotites, many of them with gabbroic or pyroxenitic dykelets, and slightly more frequent basalts (11\%) and gabbros (4\%) than in the western corridor. Although this shows a less starved magmatic supply than in the western corridor, the TOBI images of the smooth areas in the eastern corridor show that the basaltic carapace is highly discontinuous and no more than $\sim 300 \mathrm{~m}$ in thickness. Such a thin igneous crust agrees well with high residual mantle Bouguer anomalies for smooth seafloor areas ${ }^{14}$. Lower residual mantle Bouguer anomaly values suggesting thicker crust characterize the north of the eastern corridor ${ }^{14}$ where 2 corrugated surfaces have been imaged (Fig. 3 and Supplementary Fig. S2) and where dredges recovered up to $25 \%$ gabbros (dredges no. 33-34, Supplementary Table S1).

\section{Unroofing of mantle-derived rocks by detachment faults}

The only way to emplace mantle-derived rocks at the sea floor is through faulting ${ }^{18-21}$. We interpret the smooth areas on TOBI images as relict surfaces of large detachment faults. Detachment faults recognized at more magmatically robust ridge sections of slow- to ultraslow-spreading ridges predominantly produce domal corrugated surfaces or oceanic core complexes extending for $10-20 \mathrm{~km}$ parallel to the axis and exhuming mantle-derived peridotites with significant proportions of gabbros ${ }^{22-27}$. In contrast, in the magma-starved SWIR corridors studied here, exhumation surfaces are more or less planar, without corrugations, extend up to $60 \mathrm{~km}$ along axis ${ }^{14}$ and expose almost exclusively mantle-derived rocks. Furthermore, inferred former detachment faults face both towards and away from the ridge axis, and form either symmetric ridges with steep sides or asymmetric ridges with gentle inwardfacing slopes and steeper outward-facing slopes. Both this diversity of fault dips and the cross-cutting relationships support a rolling hinge model that predicts a rotation and flattening of initially steep fault scarps in response to flexural unloading during stretching ${ }^{28}$. The sharp summit of the Cannibal Ridge, with no evidence for a break in slope suggestive of a flat-topped horst, and the off-centre location of the ridge axis at the foot of the northern side of this ridge do not argue for a central horst block with symmetric extension. Rather, we suggest that this symmetric ridge results from two phases of asymmetric extension, the southern side being the relict of an early detachment fault cut and back-tilted by a later fault on the northern side. We further speculate that fault capture may be more frequent for virtually amagmatic spreading, leading to symmetric ridges as in the western corridor. In contrast, for a less magma-starved budget, as in the eastern corridor, less frequent fault capture would lead to the generation of asymmetric ridges, in consequence allowing mantle lithosphere to be exhumed over spreading-direction-parallel distances of $>17 \mathrm{~km}$. Multiple shifts in 


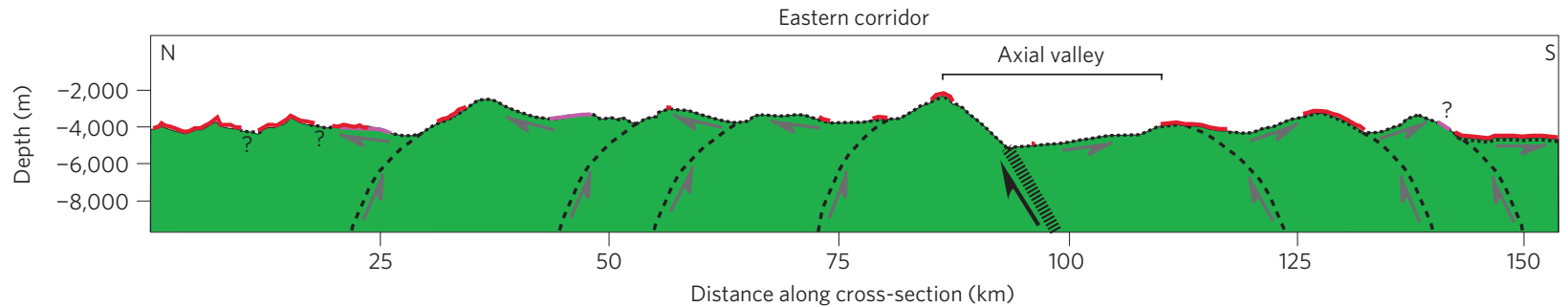

b

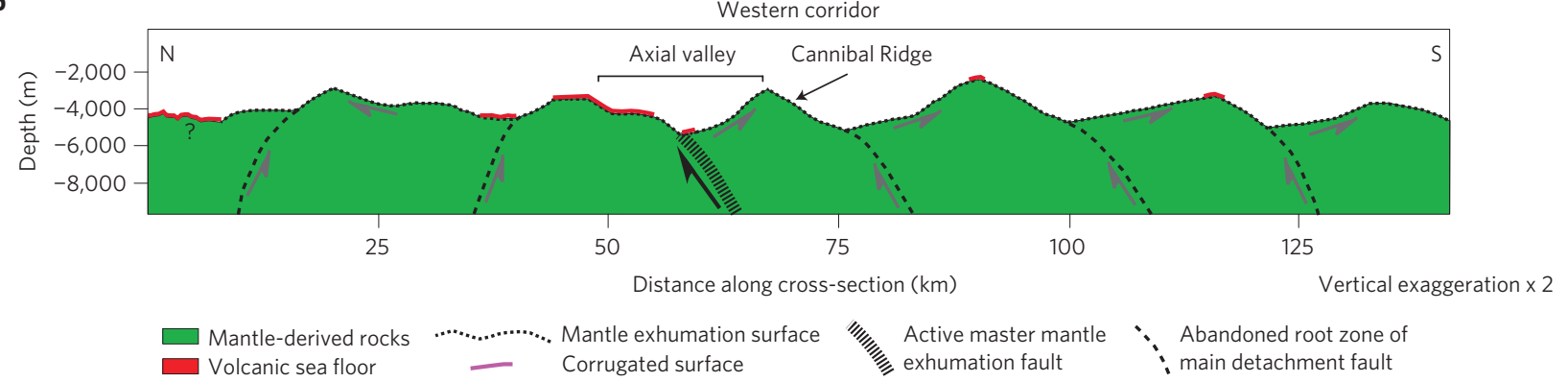

Figure 3 | Simplified geological sections in two smooth seafloor areas. a,b, The cross-sections in the eastern (a) and western (b) corridors are based on bathymetry and dredging data. The different types of sea floor are deduced from the interpretation of the TOBI side-scan sonar images. The detachment geometry at depth is pure speculation using results of numerical models of oceanic detachment fault formation ${ }^{47,48}$. Internal deformation of the footwall of these detachments may be heterogeneous as suggested by patterns of fine-scale lineaments within the smooth areas on TOBI images. See location of the cross-sections in Fig. 2 for the axial domain and in Supplementary Figs S1-S2.

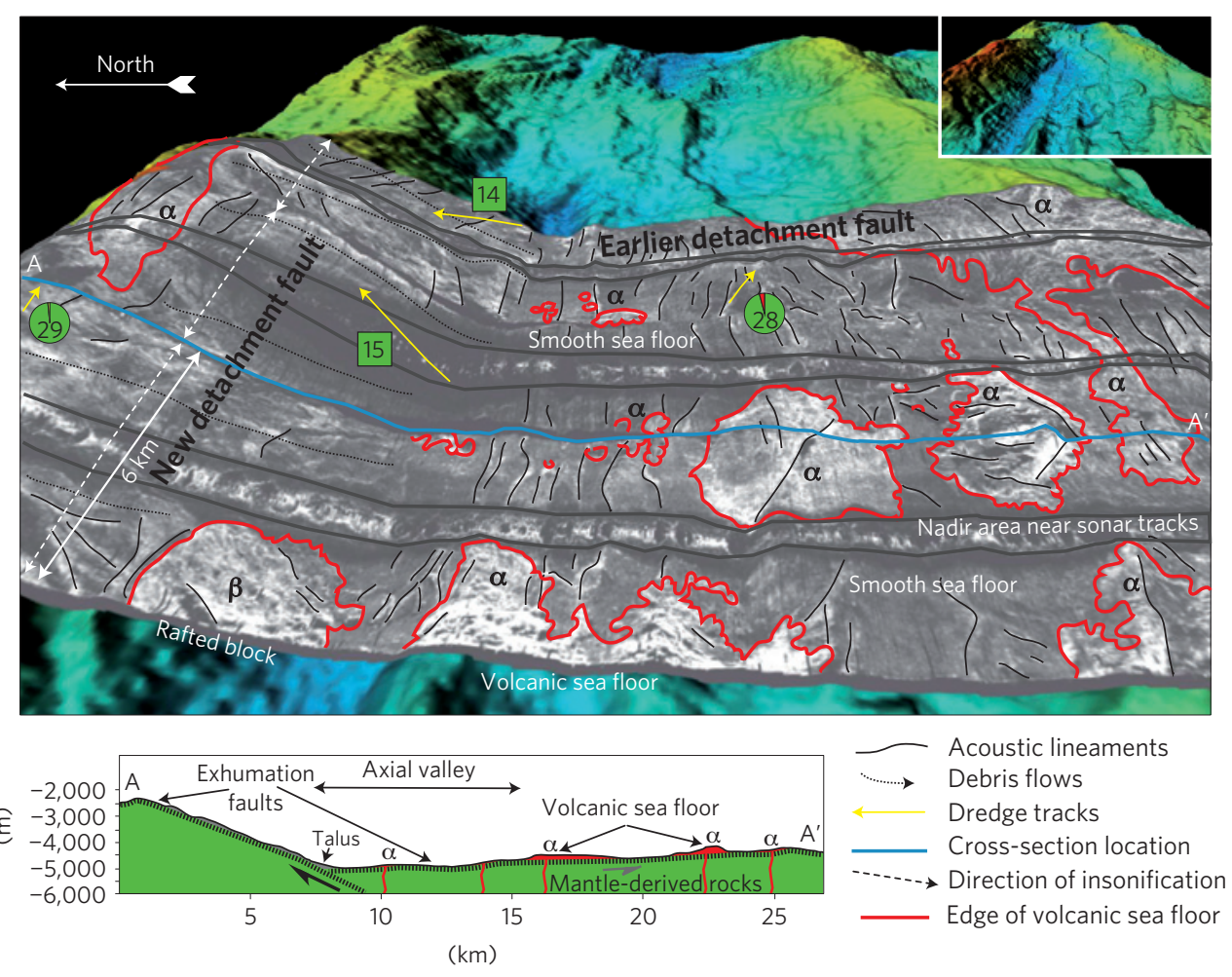

Figure 4 | Eastward three-dimensional view of the axial valley in the eastern survey area and interpretative cross-section (1.5 and no vertical exaggeration respectively). TOBI side-scan sonar images are draped over bathymetric data and show smooth seafloor and volcanic textures. The steeper northern valley wall exhumes mantle-derived rocks and cuts the axial valley floor that corresponds to an earlier mantle exhumation surface. Small patches of lavas $(\alpha)$ are erupted directly onto this earlier detachment surface; another patch $(\beta)$ is rafted on the new fault surface. A discontinuous pattern of fine-scale ridge-parallel acoustic lineaments locally affects the smooth areas. The pie charts are as in Fig. 1.

the polarity of axial valley-bounding detachment faults may lead to the essentially symmetrical overall tectonic pattern ${ }^{14}$ observed for the past $11 \mathrm{Myr}$ (ref. 16). This view contrasts with the results of present numerical models of oceanic core complex formation that predict that long-lived detachment may not form when there is little to no melt accretion ${ }^{29}$. This suggests that the rheology and dynamics of detachment faults in melt-starved exhumation contexts are not adequately reproduced in these models. 

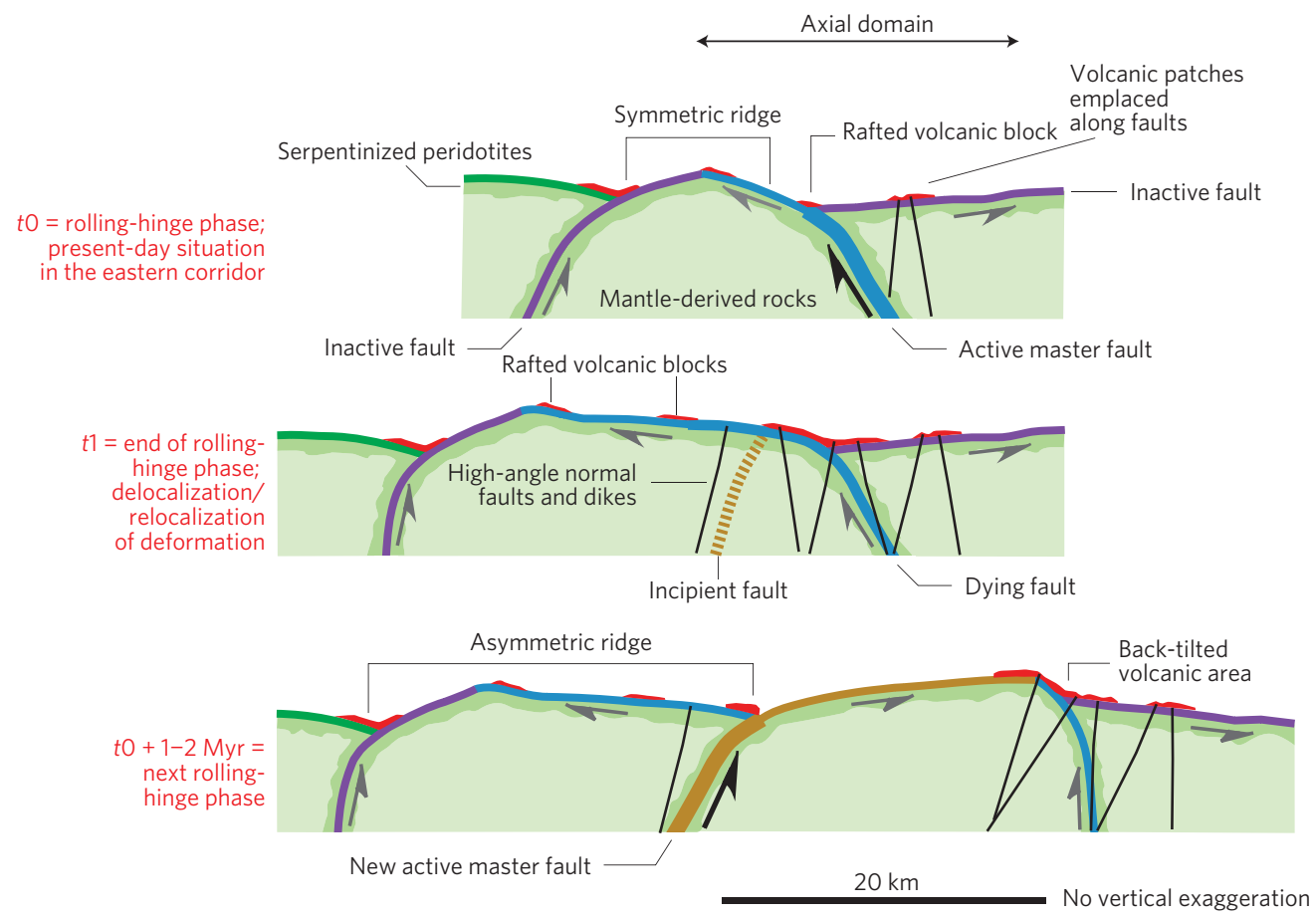

Figure 5 | Schematic illustration of the flip-flop model of continuous exhumation of mantle-derived rocks at the eastern magma-poor part of the SWIR. Successive polarity changes of asymmetric rolling-hinge detachments lead to symmetric expanses of exhumed mantle-derived rocks. Delocalization and relocalization of the deformation may be related to a subdued magmatic system resulting in short-lived episodes of volcanism, and enhanced hydrothermal fluid circulation and serpentinization next to fault-controlled dykes favouring the initiation of new detachments.

On the Mid-Atlantic Ridge, basalts are generally found in blocks inferred to be hanging wall or rider blocks to the detachment $t^{30-32}$. Although we found evidence for a hanging wall block that may be in the early stage of being rafted over the emerging detachment surface in the eastern corridor (Fig. 4), our detailed mapping shows that small patches of lavas were also erupted directly onto the exhumed detachment surfaces, indicating a sparse but continual sputtering volcanic activity during exhumation. The larger and more continuous volcanic areas are observed on outward-facing detachment surfaces and above the ridge crests where more recent detachment faults are assumed to initiate, suggesting that volcanism increased in the later stages of activity of each successive detachment and therefore could control, at least partly, the abandonment and formation of successive detachments with opposite polarity.

\section{Mechanisms for continuous mantle exhumation}

Figure 5 schematically illustrates the main aspects of our conceptual flip-flop model for continuous exhumation of mantle-derived rocks at ultraslow-spreading ridges with very low melt supply. The most prominent structures are detachment faults with $>17 \mathrm{~km}$ displacements. They root at high angles with footwalls being flexurally rotated during unroofing to form low-angle inactive exhumation surfaces ${ }^{33,34}$. Further rotation of the exhumed fault surfaces may also occur in the hanging wall of subsequent, reverse polarity, detachments. These inactive exhumation surfaces are dissected by high-angle normal faults and are then covered by sparse volcanics. These high-angle faults have very small offsets but seem to guide volcanic injections, which are most abundant in domains where the next detachment is assumed to initiate. The development of these steep faults may be a consequence of an increase in flexural rigidity and hence strengthening of the footwall ${ }^{35,36}$. Although the cause for such a rheological change is not known, it may signal the end of the activity of the detachment. As the exposed detachment surface lengthens with time, the emergence zone may migrate relative to the adjacent plate boundary, ultimately leading to the active portion of the fault at depth moving across this boundary ${ }^{25,37}$. In our interpretation, one of these later steep faults, cutting up through the footwall, is weakened by localized serpentinization and becomes the new master fault. Delocalization and relocalization of the deformation may thus be linked with magmatism, even in this very meltpoor spreading context. We predict that even small volumes of melt, emplaced as dykes in the upper lithosphere, may enhance hydrothermal circulation, leading to more efficient serpentinization and subsequent rheological weakening in the ultramafics ${ }^{35,36}$. Repetitions of detachment formation and abandonment leave on both flanks of the ridge expanses of mantle-derived rocks topped by exhumed detachment surfaces and a series of outward-dipping abandoned root zones of successive detachment faults. Fault polarities are likely to alternate if flexure of the exhuming footwall induces strain weakening antithetic to the old fault. Repeating this process leads to an overall symmetric mantle exhumation, although each phase of faulting is highly asymmetric. This is in agreement with equivalent distances between the axis and magnetic anomaly C5n.o (11 Myr) on both African and Antarctic plates ${ }^{16}$.

\section{The SWIR as an analogue for ocean-continent transitions}

Similar tectonic processes are expected in ocean-continent transitions of magma-poor passive margins where large domains of serpentinized peridotites are inferred beneath sedimentary formations $s^{38,39}$. There, multiple mantle shear zones may also explain the symmetrical unroofing of broad expanses of mantle-derived rocks observed at such margins ${ }^{40}$. Interpreted seismic sections of the Newfoundland-Iberia margin system show early low-angle detachments, separating crustal blocks from serpentinized mantle, which were cut and back-rotated by later steep faults that were, in turn, rotated to a low angle as they exhumed mantle-derived rocks in their footwalls ${ }^{41}$. In the Tasna ancient ocean-continent transition (southeastern Swiss Alps) such a mantle exhumation 
surface truncated by another detachment fault is exposed and can be observed on a kilometric scale ${ }^{42}$. Magma-poor margins share thus some key characteristics with magma-starved sections of the ultraslow-spreading SWIR: both are characterized by very little magmatism and the unroofing of mantle rocks over tens of kilometres. The reason why a new master fault initiates and cuts through the existing footwall of an earlier fault is not well understood in ocean-continent transition contexts. Ultraslowspreading ridges may provide a useful present-day analogue to further explore the tectono-magmatic relationships at magma-poor divergent plate boundaries ${ }^{43}$.

\section{Methods}

TOBI (ref. 44) carries, together with other instruments, a $30 \mathrm{kHz}$ side-scan sonar that illuminates the sea floor to obtain backscatter images at a resolution of $3 \mathrm{~m}$ These sonar data were processed, gain equalized, filtered to remove striping and speckle noise, and projected into geographic coordinates ${ }^{45}$. The position of the TOBI vehicle was estimated using a towing simulation program that takes account of varying tow cable length and vehicle depth. We estimated the accuracy of the obtained navigation to be about $100-500 \mathrm{~m}$ by comparing prominent features visible on both side-scan and multibeam bathymetry maps. In interpreting the side-scan sonar data we followed similar principles to previous authors ${ }^{17,46}$ to divide the sonar images into a number of different acoustic terrains. We used the dredged samples to ground-truth our sonar interpretations, and then compiled these interpretations into geological maps of the eastern and western corridors (Supplementary Figs S1 and S2). We separated the hummocky morphology from smooth terrains very carefully leading to a conservative map where the extension of smooth terranes is minimized and the volcanic terranes are maximized. The hummocky texture consists of large conglomerations of subcircular mounds, individually with $<200 \mathrm{~m}$ diameters that can be most readily attributed to individual pillow lava flows ${ }^{17}$. Lava flows or lava ponds with relatively flat and strongly reflective surfaces were observed only in the volcanic regions outside the eastern and western corridors ${ }^{13}$. Smooth homogeneous areas with more or less sediment draping are generally low-backscatter surfaces. However, they show sometimes a highly backscattering mottled texture that we tentatively attribute to serpentinized peridotite blocks covered by a few-centimetre-thick manganese layer. No striations are observed except in two corrugated surfaces that were already identified with multibeam bathymetric data in the northern part of the western corridor ${ }^{35}$. A fine-scale irregular, curved and discontinuous pattern of 200-600-m-spaced and ridge-parallel acoustic lineaments locally interrupts the smooth terrains. These lineaments correspond either to recent scarps of small high-angle normal faults or to an older fracture schistosity. Both suggest a complex and heterogeneous internal deformation history of the footwall of the detachment faults. Sediment ponding and mass-wasting features such as talus were also mapped.

\section{Received 29 October 2012; accepted 13 February 2013; published online 24 March 2013}

\section{References}

1. Dick, H. J. B., Lin, J. \& Schouten, H. An ultraslow-spreading class of ocean ridge. Nature 426, 405-412 (2003).

2. Sauter, D. \& Cannat, M. in Diversity of Hydrothermal Systems on Slow-Spreading Ocean Ridges (eds Peter, R., Colin, D., Jérome, D. \& Bramley, M.) 153-173 (Geophysical Monograph Series, Vol. 188, AGU, 2010).

3. Patriat, P., Sloan, H. \& Sauter, D. From slow to ultra-slow: A previously undetected event at the Southwest Indian Ridge at $\sim 24 \mathrm{Myr}$. Geology 36, 207-210 (2008).

4. Cannat, M. et al. Spreading rate, spreading obliquity, and melt supply at the ultraslow spreading Southwest Indian Ridge. Geochem. Geophys. Geosyst. 9, Q04002 (2008)

5. Cannat, M., Rommevaux-Jestin, C., Sauter, D., Deplus, C. \& Mendel, V. Formation of the axial relief at the very slow spreading Southwest Indian Ridge (49 -69 E). J. Geophys. Res. 104, 22825-22843 (1999).

6. Sauter, D. et al. From slow to ultra-slow: How does spreading rate affect seafloor roughness and crustal thickness? Geology 39, 911-914 (2011).

7. Meyzen, C. M., Toplis, M. J., Humler, E., Ludden, J. N. \& Mével, C. A discontinuity in mantle composition beneath the southwest Indian Ridge. Nature 421, 731-733 (2003).

8. Seyler, M., Brunelli, D., Toplis, M. J. \& Mével, C. Multiscale chemical heterogeneities beneath the eastern Southwest Indian Ridge $\left(52^{\circ} \mathrm{E}-68^{\circ} \mathrm{E}\right)$ : Trace element compositions of along axis dredged peridotites. Geochem. Geophys. Geosyst. 12, Q0AC15 (2011).

9. Seyler, M., Cannat, M. \& Mével, C. Evidence for major-element heterogeneity in the mantle source of abyssal peridotites from the Southwest Indian Ridge $\left(52^{\circ}\right.$ to $\left.69^{\circ} \mathrm{E}\right)$. Geochem. Geophys. Geosyst. 4, 9101 (2003).
10. Minshull, T. A., Muller, M. R. \& White, R. S. Crustal structure of the Southwest Indian Ridge at $66^{\circ}$ E: Seismic constraints. Geophys. J. Int. 166, 135-147 (2006).

11. Mendel, V., Sauter, D., Parson, L. \& Vanney, J-R. Segmentation and morphotectonic variations along a super-slow spreading centre: The Southwest Indian Ridge (57 E-70 E). Mar. Geophys. Res. 19, 505-533 (1997).

12. Sauter, D. et al. Ridge segmentation and the magnetic structure of the Southwest Indian Ridge (at 55 $30^{\prime} \mathrm{E}, 55^{\circ} 30^{\prime} \mathrm{E}$ and $66^{\circ} 20^{\prime} \mathrm{E}$ ): Implications for magmatic processes at ultraslow-spreading centres. Geochem. Geophys. Geosyst. 5, Q05K08 (2004).

13. Sauter, D. et al. Focused magmatism versus amagmatic spreading along the ultra-slow spreading Southwest Indian Ridge: Evidence from TOBI side scan sonar imagery. Geochem. Geophys. Geosyst. 5, Q10K09 (2004).

14. Cannat, M. et al. Modes of seafloor generation at a melt-poor ultraslow-spreading ridge. Geology 34, 605-608 (2006).

15. Snow, J. E. et al. Oblique nonvolcanic seafloor spreading in Lena Trough, Arctic Ocean. Geochem. Geophys. Geosyst. 12, Q10009 (2011).

16. Sauter, D., Cannat, M. \& Mendel, V. Magnetization of 0-26.5 Myr seafloor at the ultraslow spreading Southwest Indian Ridge 61-67 E. Geochem. Geophys. Geosyst. 9, Q04023 (2008).

17. Searle, R. C. et al. Structure and development of an axial volcanic ridge: Mid-Atlantic Ridge, $45^{\circ}$ N. Earth Planet. Sci. Lett. 299, 228-241 (2010).

18. Cannat, M. et al. Thin crust, ultramafic exposures, and rugged faulting patterns at the Mid-Atlantic Ridge $\left(22^{\circ}-24^{\circ} \mathrm{N}\right)$. Geology 23, 49-52 (1995).

19. Karson, J. A. et al. Along axis variations in seafloor spreading in the MARK Area. Nature 328, 681-685 (1987).

20. Dick, H. J. B., Thompson, W. B. \& Bryan, W. B. Low angle faulting and steady-state emplacement of plutonic rocks at ridge-transform intersections. EOS Trans. Am. Geophys. Union 62, 406 (1981).

21. Tucholke, B. E. \& Lin, J. A geological model for the structure of ridge segments in slow-spreading ocean crust. J. Geophys. Res. 99, 11937-11958 (1994).

22. Cann, J. R. et al. Corrugated slip surfaces formed at North Atlantic ridge-transform intersections. Nature 385, 329-332 (1997).

23. Escartin, J. et al. Central role of detachment faults in accretion of slow-spreading oceanic lithosphere. Nature 455, 790-794 (2008).

24. Smith, D. K., Cann, J. R. \& Escartin, J. Widespread active detachment faulting and core complex formation near 13 degrees $\mathrm{N}$ on the Mid-Atlantic Ridge. Nature 442, 440-443 (2006).

25. MacLeod, C. J. et al. Life cycle of oceanic core complexes. Earth Planet. Sci. Lett. 287, 333-344 (2009).

26. Hayman, N. W. et al. Oceanic core complex development at the ultraslow spreading Mid-Cayman Spreading Center. Geochem. Geophys. Geosyst. 12, Q0AG02 (2011)

27. Cheadle, M. \& Grimes, C. Structural geology: To fault or not to fault. Nature Geosci. 3, 454-456 (2010).

28. Lavier, L., Buck, W. R. \& Poliakov, A. N. B. Self-consistent rolling-hinge model for the evolution of large-offset low-angle normal faults. Geology 27, 1127-1130 (1999).

29. Olive, J-A., Behn, M. D. \& Tucholke, B. E. The structure of oceanic core complexes controlled by the depth distribution of magma emplacement. Nature Geosci. 3, 491-495 (2010).

30. Blackman, D. K., Canales, J. P. \& Harding, A. Geophysical signatures of oceanic core complexes. Geophys. J. Int. 178, 593-613 (2009).

31. Escartín, J., Mével, C., MacLeod, C. J. \& McCaig, A. M. Constraints on deformation conditions and the origin of oceanic detachments: The Mid-Atlantic Ridge core complex at $15^{\circ} 45^{\prime}$ N. Geochem. Geophys. Geosyst. 4, 1067 (2003).

32. Reston, T. J. \& Ranero, C. R. The 3-D geometry of detachment faulting at mid-ocean ridges. Geochem. Geophys. Geosyst. 12, Q0AG05 (2011).

33. deMartin, B. J., Sohn, R. A., Pablo Canales, J. \& Humphris, S. E. Kinematics and geometry of active detachment faulting beneath the Trans-Atlantic Geotraverse (TAG) hydrothermal field on the Mid-Atlantic Ridge. Geology 35, 711-714 (2007).

34. MacLeod, C. J., Carlut, J., Escartín, J., Horen, H. \& Morris, A. Quantitative constraint on footwall rotations at the $15^{\circ} 45^{\prime} \mathrm{N}$ oceanic core complex, Mid-Atlantic Ridge: Implications for oceanic detachment fault processes. Geochem. Geophys. Geosyst. 12, Q0AG03 (2011).

35. Cannat, M., Sauter, D., Escartín, J., Lavier, L. \& Picazo, S. Oceanic corrugated surfaces and the strength of the axial lithosphere at slow spreading ridges. Earth Planet. Sci. Lett. 288, 174-183 (2009).

36. Manatschal, G. et al. The Chenaillet Ophiolite in the French/Italian Alps: An ancient analogue for an oceanic core complex? Lithos 124, 169-184 (2011).

37. Buck, W. R., Lavier, L. L. \& Poliakov, A. N. B. Modes of faulting at mid-ocean ridges. Nature 434, 719-723 (2005).

38. Minshull, T. A. Geophysical characterization of the ocean-continent transition at magma-poor rifted margins. Comptes Rendus Geosci. 341, 382-393 (2009).

39. Whitmarsh, R. B., Manatschal, G. \& Minshull, T. A. Evolution of magma-poor continental margins from rifting to seafloor spreading. Nature 413, 150-154 (2001). 
40. Welford, J. K. et al. Structure and rifting evolution of the northern Newfoundland Basin from Erable multichannel seismic reflection profiles across the southeastern margin of Flemish Cap. Geophys. J. Int. 180, 976-998 (2010).

41. Reston, T. J. \& McDermott, K. G. Successive detachment faults and mantle unroofing at magma-poor rifted margins. Geology 39, 1071-1074 (2011).

42. Manatschal, G. et al. What is the tectono-metamorphic evolution of continental break-up: The example of the Tasna Ocean-Continent Transition. J. Struct. Geol. 28, 1849-1869 (2006).

43. Cannat, M., Manatschal, G., Sauter, D. \& Péron-Pinvidic, G. Assessing the conditions of continental breakup at magma-poor rifted margins: What can we learn from slow spreading mid-ocean ridges? Comptes Rendus Geosci. 341, 394-405 (2009).

44. Flewellen, C., Millard, N. \& Rouse, I. TOBI, a vehicle for deep ocean survey. Electron. Commun. Eng. J. 5, 85-93 (1993).

45. Le Bas, T. P., Mason, D. C. \& Millard, N. C. TOBI image processing-the state of the art. IEEE J. Ocean Eng. 20, 85-93 (1995).

46. Sauter, D. et al. TOBI sidescan sonar imagery of the very slow-spreading Southwest Indian Ridge: Evidence for along axis magma distribution. Earth Planet. Sci. Lett. 1999, 81-95 (2002).

47. Lavier, L. \& Manatschal, G. A mechanism to thin the continental lithosphere at magma-poor margins. Nature 440, 324-238 (2006).
48. Tucholke, B. E., Behn, M. D., Buck, W. R. \& Lin, J. Role of melt supply in oceanic detachment faulting and formation of megamullions. Geology 36, 455-458 (2008).

\section{Acknowledgements}

Funding was provided by ANR grant 'Rift2Ridge' and support by INSU/CNRS and IPEV. This is IPGP contribution 3370 .

\section{Author contributions}

D.S. and M.C. conceived the project and wrote the article. All authors participated in the RV Marion Dufresne MD183 cruise, and contributed to discussions, interpretation of results and manuscript writing.

\section{Additional information}

Supplementary information is available in the online version of the paper. Reprints and permissions information is available online at www.nature.com/reprints. Correspondence and requests for materials should be addressed to D.S.

\section{Competing financial interests}

The authors declare no competing financial interests. 